\title{
ANALISIS FAKTOR-FAKTOR YANG MEMPENGARUHI HARGA SAHAM DENGAN NILAI PERUSAHAAN SEBAGAI VARIABEL INTERVENING
}

\author{
Danarji Nirmolo; Kesi Widjajanti \\ danarji.nirmolo@gmail.com
}

Magister Manajemen, Universitas Semarang, Semarang, Indonesia

\begin{tabular}{l} 
Info Artikel \\
\hline Sejarah Artikel: \\
Diterima \\
Disetujui \\
Dipublikasikan \\
\hline Keywords: \\
firm value; fundamental \\
analysis; stock price
\end{tabular}

\begin{abstract}
Abstrak
Tujuan penelitian ini adalah untuk menganalisis pengaruh dari variabel debt to equity ratio (DER), dividend payout ratio (DPR), earning per share (EPS) terhadap nilai perusahaan (PBV) dan pengaruh DER, DPR, EPS, dan PBV terhadap harga saham pada perusahaan yang tercatat dalam indeks LQ45 di Bursa Efek Indonesia periode 2014 -2017. Penelitian menggunakan metode purposive sampling untuk pengambilan sampel. Data diperoleh berdasarkan data laporan keuangan perusahaan dan laporan statistik tahunan yang berasal dari www.idx.co.id, diperoleh jumlah sampel sebanyak 30 perusahaan. Teknik analisis yang digunakan adalah analisis regresi data panel. Berdasarkan uji statistik $\mathrm{F}$ menunjukkan bahwa kedua model memenuhi kriteria fit karena memiliki nilai signifikansi yang kurang dari $\alpha 0,05$. Sedangkan berdasarkan uji statistik $t$ menunjukkan bahwa debt to equity ratio berpengaruh positif dan signifikan terhadap nilai perusahaan karena memiliki nilai signifikansi kurang dari $\alpha \quad 0,05$. Sedangkan variabel dividend payout ratio dan earning per share tidak berpengaruh signifikan terhadap nilai perusahaan. Variabel debt to equity ratio tidak berpengaruh signifikan terhadap harga saham, sedangkan dividend payout ratio berpengaruh negatif dan signifikan terhadap harga saham. Earning per share dan nilai perusahaan berpengaruh positif dan signifikan terhadap harga saham.
\end{abstract}

\section{JUDUL BAHASA INGGRIS}

\begin{tabular}{|c|c|}
\hline & Abstract \\
\hline & $\begin{array}{l}\text { The purpose of this study is to analyze the impact of the variables debt to equity ratio (DER), } \\
\text { dividend payout ratio (DPR), and earning per share (EPS) toward firm value (PBV) and the } \\
\text { influence of DER, DPR, EPS, and PBV toward price stock on companies listed in the LQ45 } \\
\text { index on the Indonesia Stock Exchange in the } 2014 \text { - 2017. Research using purposive sampling } \\
\text { method for taking samples. Data obtained from company financial reports and yearly statistic } \\
\text { reports of Indonesia Stock Exchange listed at IDX (www.idx.co.id), obtained } 30 \text { samples of firms. } \\
\text { Analysis technique used is panel data regression analysis. Based on the test statistic F indicates } \\
\text { that both of the model is fit because has a significance value less than 0,05 of } \alpha \text {. Meanwhile, based } \\
\text { on statistical t test showed that debt to equity ratio has positive and significant impact on firm } \\
\text { value because it has a significance value less than 0,05 of } \alpha \text { although dividend payout ratio and } \\
\text { earning per share don't have significant impact on firm value. Meanwhile, debt to equity ratio } \\
\text { doesn't have significant impact on stock price but dividend payout ratio has negative and } \\
\text { significant impact on stock price. Earning per share and firm value have positive and significant } \\
\text { impact on stock price. }\end{array}$ \\
\hline Alamat korespondensi : & ISSN \\
\hline Magister Manajemen, U & 1979-480o (cetak) \\
\hline E-mail: (danarji.nirmolo & $2580-8451$ (online) \\
\hline
\end{tabular}




\section{PENDAHULUAN}

Tujuan dari investasi saham adalah mendapatkan earning yaitu pembagian dividen dan capital gain dengan cara menjual saham dengan nilai lebih besar dari pembelian sebelumnya. Untuk mendapatkan keuntungan dari penjualan saham, investor perlu mempertimbangkan faktor-faktor yang mempengaruhi harga saham perusahaan dan mengetahui perusahaan yang mempunyai kinerja bagus sehingga diharapkan harga sahamnya dapat naik di masa mendatang. Untuk itu, investor perlu melakukan analisis fundamental yaitu analisis yang menitikberatkan pada rasio finansial dan kejadiankejadian yang secara langsung maupun tidak langsung mempengaruhi kinerja keuangan perusahaan (Tandelilin, 2010). Rasio-rasio finansial yang dapat digunakan diantaranya yaitu Debt to Equity Ratio (DER), Dividend Payout Ratio (DPR), Earning Per Share (EPS), dan Price to Book Value (PBV). Beberapa peneliti telah mencoba mengevaluasi faktor-faktor apa saja yang dapat mempengaruhi harga saham tetapi hasilnya tidak konsisten. Oleh sebab itu, penelitian ini bertujuan untuk menguji kembali faktor-faktor yang mempengaruhi harga saham yaitu Debt to Equity Ratio (DER), Dividend Payout Ratio (DPR), Earning Per Share (EPS), dan nilai perusahaan yang diproksikan dengan Price to Book Value (PBV) dengan nilai perusahaan sebagai variabel intervening.

\section{TELAAH PUSTAKA}

\section{Pengaruh Debt to Equity Ratio terhadap Nilai Perusahaan}

Debt to Equity Ratio (DER) merupakan rasio untuk mengetahui kemampuan perusahaan dalam membayar hutang jika perusahaan tersebut dilikuidasi. (Ashari, 2010 dalam Mayangsari, 2015). Semakin tinggi DER menunjukkan bahwa perusahaan lebih banyak menggunakan hutang daripada ekuitas pemegang saham untuk menjalankan perusahaannya. Sebaliknya, semakin rendah DER menunjukkan porsi hutang perusahaan lebih kecil daripada ekuitas pemegang saham, sehingga laba perusahaan dapat dimaksimalkan untuk membagikan dividen ke pemegang saham, menjadikan nilai perusahaan baik di mata investor. Hal ini didukung oleh penelitian Nasehah dan Widyarti (2012) dan Chaidir yang mengungkapkan bahwa DER berpengaruh negatif terhadap PBV.

Berdasarkan uraian tersebut maka hipotesis dalam penelitian ini dapat dirumuskan sebagai berikut:

H1: Diduga Debt to Equity Ratio berpengaruh negatif terhadap nilai perusahaan

\section{Pengaruh Dividend Payout Ratio terhadap Nilai Perusahaan}

Dividend Payout Ratio (DPR) merupakan laba yang diterima oleh para pemegang saham dari laba bersih yang diperoleh perusahaan. (Mayangsari, 2015). Semakin tinggi DPR menunjukkan laba perusahaan lebih diutamakan untuk pembagian dividen ke pemegang saham sehingga investor tertarik untuk berinvestasi di perusahaan tersebut dengan harapan akan mendapatkan dividen dalam jumlah besar. Ketertarikan investor pada perusahaan tersebut menjadikan nilai perusahaan tinggi di mata investor. Hal ini didukung oleh penelitian Nasehah dan Widyarti yang mengungkapkan bahwa DPR berpengaruh positif terhadap PBV.

Berdasarkan uraian tersebut maka hipotesis dalam penelitian ini dapat dirumuskan sebagai berikut:

H2: Diduga Dividend Payout Ratio berpengaruh positif terhadap nilai perusahaan 


\section{Pengaruh Earning Per Share terhadap Nilai Perusahaan}

Laba merupakan alat ukur utama kesuksesan suatu perusahaan, karena itu para pemodal seringkali memusatkan perhatian pada besarnya EPS dalam melakukan analisis saham. Pengertian Earning Per Share (EPS) menurut Kasmir (2012) merupakan rasio untuk mengukur keberhasilan manajemen dalam mencapai keuntungan bagi pemegang saham. Semakin tinggi nilai EPS tentu saja menggembirakan pemegang saham karena semakin besar laba yang disediakan untuk pemegang saham yang nantinya akan diberikan kepada pemegang saham dalam bentuk dividen. Semakin tinggi EPS berarti semakin baik nilai perusahaan di mata investor. Chaidir (2015) meneliti bahwa EPS berpengaruh positif terhadap harga saham.

Berdasarkan uraian tersebut maka hipotesis dalam penelitian ini dapat dirumuskan sebagai berikut:

H3: Diduga Earning Per Share berpengaruh positif terhadap nilai perusahaan

\section{Pengaruh Debt to Equity Ratio terhadap Harga Saham}

Debt to Equity Ratio (DER) menunjukkan perbandingan antara hutang dengan ekuitas pemegang saham. Semakin rendah DER menunjukkan bahwa perusahaan mempunyai struktur modal dengan porsi hutang yang lebih sedikit, sehingga laba perusahaan dapat digunakan untuk mengembangkan perusahaan atau dibagikan dalam bentuk dividen ke pemegang saham. Semakin tinggi dan sering dividen yang diberikan ke pemegang saham, semakin banyak investor tertarik untuk membeli saham perusahaan tersebut, sehingga semakin banyak investor membeli saham membuat harga saham menjadi naik. Hal ini didukung oleh penelitian Dewi dan Suaryana (2013) dan Sari dan Santoso (2017) yang mengungkapkan bahwa DER berpengaruh positif terhadap harga saham.

Berdasarkan uraian tersebut maka hipotesis dalam penelitian ini dapat dirumuskan sebagai berikut:

H4: Diduga Debt to Equity Ratio berpengaruh negatif terhadap harga saham

\section{Pengaruh Dividend Payout Ratio terhadap Harga Saham}

Dividend Payout Ratio (DPR) merupakan laba yang diterima oleh para pemegang saham dari laba bersih yang diperoleh perusahaan. (Mayangsari, 2015). Semakin tinggi DPR menunjukkan laba perusahaan lebih diutamakan untuk pembagian dividen ke pemegang saham sehingga investor tertarik untuk berinvestasi di perusahaan tersebut dengan harapan akan mendapatkan dividen dalam jumlah besar. Semakin tinggi dividen yang diberikan ke pemegang saham, semakin banyak investor tertarik untuk membeli saham perusahaan tersebut, sehingga semakin banyak investor membeli saham membuat harga saham menjadi naik. Penelitian yang dilakukan oleh Rahmawati dan Suryono (2017) mendapatkan hasil bahwa DPR berpengaruh positif terhadap harga saham.

Berdasarkan uraian tersebut maka hipotesis dalam penelitian ini dapat dirumuskan sebagai berikut:

H5: Diduga Dividend Payout Ratio berpengaruh positif terhadap harga saham

Pengaruh Earning Per Share terhadap Harga Saham

Laba merupakan alat ukur utama kesuksesan suatu perusahaan, karena itu para pemodal seringkali memusatkan perhatian pada besarnya EPS dalam melakukan analisis saham. Semakin tinggi nilai EPS tentu saja menggembirakan pemegang saham karena semakin besar laba yang disediakan untuk pemegang saham yang nantinya akan diberikan kepada pemegang saham dalam bentuk dividen. Ketertarikan investor untuk 
berinvestasi di perusahaan tersebut mengakibatkan banyak pembelian saham oleh investor sehingga menyebabkan harga saham perusahaan menjadi naik. Hal ini didukung oleh penelitian Dewi dan Suaryana (2013), Rahmawati dan Suryono (2017), dan Sari dan Santoso (2017) yang mengungkapkan bahwa EPS berpengaruh positif terhadap harga saham.

Berdasarkan uraian tersebut maka hipotesis dalam penelitian ini dapat dirumuskan sebagai berikut:

H6: Diduga Earning Per Share berpengaruh positif terhadap harga saham

\section{Pengaruh Nilai Perusahaan terhadap Harga Saham}

PBV merupakan salah satu indikator yang digunakan untuk menilai kinerja perusahaan. (Herdiningsih, 2000 dalam Hidayati, 2010). Semakin besar rasio PBV maka semakin tinggi suatu perusahaan dinilai oleh para investor dibandingkan dengan dana yang telah ditanamkan oleh perusahaan. PBV digunakan untuk mengukur kinerja harga saham terhadap nilai bukunya. Ahmed dan Nanda (2004) dalam Hidayati (2010), PBV memiliki peran penting sebagai suatu pertimbangan bagi investor untuk memilih saham yang akan dibeli dan PBV juga dapat dijadikan indikator harga atau nilai saham. Bila suatu perusahaan mempunyai PBV di atas $1(>1)$, maka harga saham perusahaan tersebut dinilai lebih tinggi daripada nilai bukunya yang menggambarkan kinerja perusahaan tersebut semakin baik di mata investor, sehingga investor akan membeli saham perusahaan tersebut dan pembelian yang meningkat akan membuat harga saham naik. Hal ini didukung oleh penelitian Dewi dan Suaryana (2013) yang mengungkapkan bahwa PBV berpengaruh positif terhadap harga saham.

Berdasarkan uraian tersebut maka hipotesis dalam penelitian ini dapat dirumuskan sebagai berikut:

H7: Diduga nilai perusahaan berpengaruh positif terhadap harga saham

\section{METODE}

\section{Jenis Penelitian}

Penelitian yang digunakan dalam penelitian ini adalah pendekatan kuantitatif dengan melakukan pengujian hipotesis. Data yang digunakan adalah data sekunder dari laporan keuangan perusahaan dan laporan statistik tahunan yang tercatat dalam IDX (www.idx.co.id) periode $2014-2017$.

\section{Populasi dan Sampel Penelitian}

Populasi pada penelitian ini adalah perusahaan yang terdaftar dalam indeks LQ45 di Bursa Efek Indonesia (BEI) periode 2014 - 2017. Teknik pengambilan sampel menggunakan metode purposive sampling yaitu perusahaan yang terdaftar secara berturut-turut dalam indeks LQ45 di Bursa Efek Indonesia periode 2014 - 2017 sehingga didapat 30 perusahaan sampel.

\section{Teknik Pengumpulan Data}

Teknik pengumpulan data yang dilakukan adalah dokumentar yaitu dengan cara mencari dan mengumpulkan data-data yang diperoleh dari sumber Bursa Efek Indonesia yaitu melalui website IDX (www.idx.co.id). Data yang digunakan untuk meneliti merupakan laporan keuangan perusahaan tahun 2014, 2015, 2016, dan 2017.

\section{Definisi Operasional dan Pengukuran Variabel}

\section{Variabel Dependen}

\section{Harga Saham}

Harga saham merupakan harga yang terbentuk pada perdagangan saham perusahaan di Bursa Efek Indonesia. Harga saham pada penelitian ini mengacu pada 
harga saham penutupan atau harga saham perusahaan pada saat penutupan di akhir tahun di Bursa Efek Indonesia.

$$
\text { Harga saham }=\text { Harga Penutupan }(\text { Closing Price })
$$

\section{Variabel Independen}

Debt to Equity Ratio

Debt to Equity Ratio dapat dirumuskan dengan membandingkan antara total liabilitas dan total ekuitas. Rasio ini untuk mengukur tingkat penggunaan utang terhadap total ekuitas yang dimiliki perusahaan.

$$
\text { Debt to Equity Ratio }=\frac{\text { Total Liabilitas }}{\text { Total Ekuitas }}
$$

\section{Dividend Payout Ratio}

Dividend Payout Ratio merupakan rasio yang menggambarkan besarnya proporsi dividen yang dibagikan terhadap pendapatan bersih perusahaan sehingga Dividend Payout Ratio dapat dirumuskan sebagai berikut:

$$
\text { Dividend Payout Ratio }=\frac{\text { Dividen Per Lembar Saham }}{\text { Pendapatan Per Lembar Saham }}
$$

\section{Earning Per Share}

Earning Per Share (EPS) adalah pendapatan bersih yang tersedia dibagi jumlah lembar saham yang beredar sehingga Earning Per Share dapat dirumuskan sebagai berikut:

$$
\text { Earning Per Share }=\frac{\text { Pendapatan Bersih }}{\text { Jumlah Saham yang Beredar }}
$$

\section{Variabel Intervening}

\section{Nilai Perusahaan}

Nilai perusahaan dalam penelitian ini diproksikan dengan Price to Book Value (PBV) yaitu membagi harga saham dengan total ekuitas per jumlah saham yang beredar sehingga dapat dirumuskan sebagai berikut:

$$
\text { Price to Book Value }=\frac{\text { Harga Saham }}{\text { (Total Ekuitas } / \text { Jumlah Saham yang beredar })}
$$

\section{Teknik Analisis Data}

\section{Statistik Deskriptif}

Statistik deskriptif ini digunakan untuk menganalisis data dengan cara mendeskripsikan atau mengambarkan data yang telah terkumpul sebagai mana adanya tanpa bermaksud membuat kesimpulan yang berlaku umum atau generalisasi.

\section{Pemilihan Model (Teknik Estimasi) Regresi Data Panel}

Menurut Widarjono (2007), ada tiga uji untuk memilih teknik estimasi data panel. Pertama, uji statistik F (uji Chou) digunakan untuk memilih antara metode Commom Effect atau metode Fixed Effect. Kedua, uji Hausman yang digunakan untuk memilih antara metode Fixed Effect atau metode Random Effect. Ketiga, uji Lagrange Multiplier (LM) digunakan untuk memilih antara metode Commom Effect atau metode Random Effect. 


\section{Pembentukan Model Regresi}

Langkah selanjutnya yaitu membentuk model persamaan regresi data panel. Karena penelitian ini menggunakan nilai perusahaan (PBV) sebagai variabel intervening, maka ada 2 persamaan model regresi yang terbentuk yaitu model pertama tentang pengaruh DER, DPR, dan EPS terhadap PBV dan model kedua yaitu pengaruh DER, DPR, EPS, dan PBV terhadap harga saham sehinggga persamaan model regresi yang terbentuk dalam penelitian ini yaitu:

$$
\begin{gathered}
P B V=\alpha+\beta_{1} D E R+\beta_{2} D P R+\beta_{3} E P S+\varepsilon \\
\operatorname{dan} \\
\text { Harga }=\alpha+\beta_{1} D E R+\beta_{2} D P R+\beta_{3} E P S+\beta_{4} P B V+\varepsilon
\end{gathered}
$$

Keterangan:

$\alpha \quad=$ konstanta

DER = Debt to Equity Ratio

DPR = Dividend Payout Ratio

EPS = Earning Per Share

$\mathrm{PBV}=$ Price to Book Value

Harga $=$ Harga Saham

$\varepsilon \quad=$ error term

\section{Uji Kelayakan (Goodness of Fit) Model Regresi Data Panel Uji Kelayakan Model (Uji F)}

Uji $F$ ini dilakukan untuk mengetahui apakah variabel independen yang digunakan dalam model penelitian mempunyai pengaruh terhadap variabel dependen. Pengujian dilakukan dengan menggunakan signifikan level $0,05(\alpha=5 \%)$. Dalam uji kelayakan model (uji f) terdapat Kriteria-kriteria untuk Mengujinya : (1) P-value < 0,05 menunjukkan bahwa uji model ini layak untuk digunakan pada penelitian. (2) P-value $>$ 0,05 menunjukkan bahwa uji model ini tidak layak untuk digunakan pada penelitian.

\section{Uji secara parsial (Uji t)}

Uji t ini pada dasarnya menunjukkan seberapa jauh pengaruh satu variabel independen secara individual dalam menerangkan variabel dependen (Ghozali, 2007). Pengujian dilakukan dengan menggunakan signifikan level $0,05(\alpha=5 \%)$. Dalam uji secara parsial (uji t) terdapat Kriteria-kriteria untuk Mengujinya : (1) Jika nilai signifikan $t>0,05$ maka (Ho) hipotesis ditolak (koefisien regresi tidak signifikan). Ini berarti secara parsial variabel independen tersebut tidak mempunyai pengaruh yang signifikan terhadap variabel dependen. (2) Jika nilai signifikan $\mathrm{t}<0,05$ maka (Ho) hipotesis diterima (koefisien regresi signifikan). Ini berarti secara parsial variabel independen tersebut mempunyai pengaruh yang signifikan terhadap variabel dependen.

\section{Koefisien Determinasi}

Koefisien Determinasi (Goodness of Fit) dinotasikan dengan $R$-squares yang merupakan suatu ukuran yang penting dalam regresi, karena dapat menginformasikan baik atau tidaknya model regresi yang terestimasi. Nilai Koefisien Determinasi mencerminkan seberapa besar variasi dari variabel terikat dapat diterangkan oleh variabel bebasnya. Bila nilai Koefisien Determinasi sama dengan 0, artinya variasi dari variabel terikat tidak dapat diterangkan oleh variabel-variabel bebasnya sama sekali. Sementara bila nilai Koefisien Determinasi sama dengan 1, artinya variasi variabel terikat secara keseluruhan dapat diterangkan oleh variabel-variabel bebasnya. Dengan 
demikian baik atau buruknya suatu persamaan regresi ditentukan oleh $R$-squares-nya yang mempunyai nilai antara nol dan satu.

\section{HASIL DAN PEMBAHASAN}

\section{Statistik Deskriptif}

Uji Analisis Deskriptif Data yang telah diproses dengan program E Views versi 8.1 dalam penelitian ini maka terdapat hasil rekapitulasi data masing-masing variabel berdasarkan hasil penelitian yang dilakukan pada tabel 1 sebagai berikut :

\section{Tabel 1}

\section{Statistik Deskriptif}

\begin{tabular}{|c|c|c|c|c|c|}
\hline & DER (x) & DPR (\%) & EPS (Rp) & PBV (x) & HARGA (Rp) \\
\hline Mean & 1.784667 & 26.140333 & 501.4750 & 4.452750 & 9839.158 \\
\hline Median & 0.960000 & 22.620000 & 250.500 & 2.605000 & 4757.500 \\
\hline Maximum & 7.210000 & 99.880000 & 3754.0000 & 66.40000 & 83800.00 \\
\hline Minimum & 0.140000 & 0.000000 & 4.0000000 & 0.330000 & 488.0000 \\
\hline Std. Dev. & 1.840443 & 25.51126 & 652.2878 & 9.093147 & 13950.89 \\
\hline
\end{tabular}

Sumber : Data Sekunder yang diolah, 2018

Berdasarkan tabel 1 di atas, rata-rata DER menunjukkan angka 1,784667. Ini menunjukkan bahwa rata-rata perusahaan yang terdaftar di indeks LQ45 selama periode 2014 - 2017 menggunakan proporsi hutang yang lebih besar 1,784667 kali terhadap ekuitasnya. Nilai minimum sebesar 0,14 dan nilai maksimum sebesar 7,21 menunjukkan bahwa dari sampel yang diteliti ada perusahaan yang hanya menggunakan proporsi utang paling sedikit sebesar 0,14 dari nilai ekuitasnya, dan ada perusahaan yang menggunakan proporsi utang paling besar yaitu 7,21 kali dari nilai ekuitasnya. Nilai median sebesar 0,96 menunjukkan bahwa dari sampel yang diteliti, separuh perusahaan menggunakan kurang dari 0,96 kali proporsi hutang terhadap ekuitasnya dan separuh perusahaan menggunakan lebih dari 0,96 kali proporsi hutang terhadap ekuitasnya.

Rata-rata DPR sebesar 26,140333 menunjukkan bahwa rata-rata perusahaan yang terdaftar di indeks LQ45 selama periode 2014 - 2017 membagikan dividen kepada pemegang saham seber $26,14 \%$ dari laba ditahannya. Nilai minimum sebesar 0 dan nilai maksimum sebesar 99,88 menunjukkan bahwa selama periode 2014 - 2017, ada perusahaaan yang terdaftar di indeks LQ45 yang pernah membagikan dividen paling rendah sebesar 0\% dari laba ditahannya (tidak membagikan dividen) kepada pemegang saham, dan ada perusahaan yang pernah membagikan dividen paling tinggi sebesar $99,88 \%$ dari laba ditahannya kepada pemegang saham. Nilai median sebesar 22,62 menunjukkan bahwa selama periode 2014 - 2017, separuh perusahaan membagikan dividen kurang dari $22,62 \%$ terhadap laba ditahannya dan separuh perusahaan membagikan dividen lebih dari 22,62\% terhadap laba ditahannya.

Rata-rata EPS sebesar 501,475 menunjukkan bahwa rata-rata perusahaan yang terdaftar di indeks LQ45 selama periode 2014 - 2017 menghasilkan laba sebesar Rp. 501,48 per lembar saham. Nilai minimum sebesar 4 dan nilai maksimum sebesar 3.754 menunjukkan bahwa selama periode 2014 - 2017, ada perusahaaan yang terdaftar di 
indeks LQ45 yang pernah menghasilkan laba per saham paling rendah sebesar Rp. 4,dan ada perusahaan yang pernah menghasilkan laba per saham paling tinggi sebesar Rp. 3.754,-- Nilai median sebesar 250,5 menunjukkan bahwa selama periode $2014-2017$, separuh perusahaan menghasilkan laba kurang dari Rp. 250,50 per lembar saham dan separuh perusahaan menghasilkan laba lebih dari Rp. 250,50 per lembar saham.

Rata-rata PBV sebesar 4,452750 menunjukkan bahwa rata-rata perusahaan yang terdaftar di indeks LQ45 selama periode 2014 - 2017 mempunyai nilai buku per lembar saham sebesar 4,452750. Nilai minimum sebesar 0,33 dan nilai maksimum sebesar 66,4 menunjukkan bahwa selama periode 2014 - 2017, ada perusahaaan yang terdaftar di indeks LQ45 yang mempunyai nilai buku per lembar saham paling rendah sebesar 0,33, dan ada perusahaan yang mempunyai nilai buku per lembar saham paling tinggi sebesar 66,4. Nilai median sebesar 2,605 menunjukkan bahwa selama periode 2014 - 2017, separuh perusahaan mempunyai nilai buku per lembar saham kurang dari 2,605 dan separuh perusahaan mempunyai nilai buku per lembar saham lebih dari 2,605.

Rata-rata HARGA sebesar 9839,158 menunjukkan bahwa rata-rata perusahaan yang terdaftar di indeks LQ45 selama periode 2014 - 2017 mempunyai harga saham sebesar Rp. 9.839,16. Nilai minimum sebesar 488 dan nilai maksimum sebesar 83.800 menunjukkan bahwa selama periode 2014 - 2017, ada perusahaaan yang terdaftar di indeks LQ45 yang mempunyai harga saham paling rendah sebesar Rp. 488,--, dan ada perusahaan yang mempunyai harga saham paling tinggi sebesar Rp. 83.800,-. Nilai median sebesar 4.757, 50 menunjukkan bahwa selama periode 2014 - 2017, separuh perusahaan mempunyai harga saham kurang dari Rp. 4.757,50 dan separuh perusahaan mempunyai harga saham lebih dari Rp. 4.757,50.

\section{Pemilihan Model (Teknik Estimasi) Regresi Data Panel}

Tahapan selanjutnya yaitu meregresikan data panel dengan menggunakan metode common effect dan metode fixed effect kemudian membandingkannya dengan uji Chou menggunakan aplikasi E Views 8.1 seperti yang ditunjukkan pada tabel 2 :

Tabel 2

Uji Chou

Redundant Fixed Effects Tests

Equation: Untitled

Test cross-section fixed effects

\begin{tabular}{llll}
\hline \hline Effects Test & Statistic & d.f. & Prob. \\
\hline \hline Cross-section F & 5.011838 & $(29,86)$ & 0.0000 \\
Cross-section Chi-square & 118.746650 & 29 & 0.0000 \\
\hline \hline
\end{tabular}

Sumber: Data diolah

Untuk menentukan metode mana yang lebih baik, dapat ditentukan menggunakan data Cross-section Chi-square yang tersaji dalam Tabel 2. Jika data Cross-section Chisquare mendapatkan hasil kurang dari 0,05 maka dapat dinyatakan bahwa metode fixed effect lebih baik dari common effect, atau sebaliknya. Dari tabel di atas, Cross-section Chi-square menunjukkan angka 0,0000 yang lebih kecil dari 0,05 sehingga dapat disimpulkan bahwa metode fixed effect lebih baik daripada common effect. 
Langkah selanjutnya membandingkan metode fixed effect dengan metode random effect dengan uji Hausman menggunakan aplikasi E Views 8.1 seperti yang ditunjukkan pada tabel 3:

\section{Tabel 3 \\ Uji Hausman}

\begin{tabular}{crrrr}
\multicolumn{2}{c}{$\begin{array}{l}\text { Correlated Random Effects - Hausman Test } \\
\text { Equation: Untitled } \\
\text { Test cross-section random effects }\end{array}$} & & \\
\hline \hline & $\begin{array}{l}\text { Chi-Sq. } \\
\text { Statistic }\end{array}$ & Chi-Sq. d.f. & Prob. \\
\hline \hline Test Summary & 36.665394 & 4 & 0.0000 \\
\hline \hline
\end{tabular}

Sumber: Data diolah

Untuk menentukan metode mana yang lebih baik, dapat ditentukan menggunakan data Cross-section random yang tersaji dalam Tabel 3. Jika data Cross-section random mendapatkan hasil kurang dari 0,05 maka dapat dinyatakan bahwa metode fixed effect lebih baik dari random effect, atau sebaliknya. Dari tabel di atas, Cross-section random menunjukkan angka 0,0000 yang lebih kecil dari 0,05 sehingga dapat disimpulkan bahwa metode fixed effect lebih baik daripada random effect. Berdasarkan uraian di atas, penelitian ini menggunakan regresi data panel dengan metode fixed effect.

\section{Pembentukan Model Regresi}

Setelah menentukan metode regresi data panel yaitu menggunakan metode fixed effect, langkah selanjutnya yaitu membentuk persamaan model regresi. Proses pembentukan persamaan model regresi yang pertama dapat dilihat pada Tabel 4.:

\section{Tabel 4 \\ Model Regresi 1}

Dependent Variable: PBV

Method: Panel Least Squares

Date: 07/02/18 Time: 02:24

Sample: 20142017

Periods included: 4

Cross-sections included: 30

Total panel (balanced) observations: 120

\begin{tabular}{crrrr}
\hline \hline Variable & Coefficient & Std. Error & t-Statistic & Prob. \\
\hline \hline C & 2.498383 & 0.937441 & 2.665110 & 0.0092 \\
DER & 0.928174 & 0.451562 & 2.055474 & 0.0428 \\
DPR & -0.008091 & 0.009897 & -0.817499 & 0.4159 \\
EPS & 0.001016 & 0.001051 & 0.966501 & 0.3365 \\
\hline \hline
\end{tabular}

Sumber: Data diolah

Berdasarkan tabel di atas, dapat dinyatakan persamaan model regresi yang pertama sebagai berikut:

$$
P B V=2,498+0,928 D E R-0,008 D P R+0,001 E P S+\varepsilon
$$


Untuk persamaan model regresi yang kedua dapat dibentuk dari data Tabel 5 :

\section{Tabel 5 \\ Model Regresi 2}

\begin{tabular}{|c|c|c|c|c|}
\hline \multicolumn{5}{|c|}{$\begin{array}{l}\text { Dependent Variable: HARGA } \\
\text { Method: Panel Least Squares } \\
\text { Date: } 07 / 02 / 18 \text { Time: } 12: 16 \\
\text { Sample: } 20142017 \\
\text { Periods included: } 4 \\
\text { Cross-sections included: } 30 \\
\text { Total panel (balanced) observations: } 120\end{array}$} \\
\hline Variable & Coefficient & Std. Error & t-Statistic & Prob. \\
\hline $\mathrm{C}$ & 2368.475 & 1250.812 & 1.893549 & 0.0616 \\
\hline DER & -534.5804 & 593.2276 & -0.901139 & 0.3700 \\
\hline DPR & -36.95101 & 12.74601 & -2.899025 & 0.0047 \\
\hline EPS & 10.50605 & 1.355559 & 7.750339 & 0.0000 \\
\hline PBV & 925.7478 & 137.5457 & 6.730475 & 0.0000 \\
\hline
\end{tabular}

Sumber: Data diolah

Berdasarkan tabel di atas, dapat dinyatakan persamaan model regresi yang kedua sebagai berikut:

Harga $=2.368,475-534,58 D E R-36,951 D P R+10,506 E P S+925,748 P B V$

$$
+\varepsilon
$$

\section{Uji Kelayakan (Goodness of Fit) Model Regresi Data Panel Uji Kelayakan Model (Uji F)}

Uji kelayakan model (uji F) bertujuan untuk mengetahui apakah semua variabel independen yang digunakan dalam model penelitian mempunyai pengaruh secara bersamaan terhadap variabel dependen. Uji Koefisien Regresi Bersama-sama (Uji F) dilakukan dengan melihat data Prob (F-statistic) dan membandingkannya dengan $\alpha$ $(0,05)$. Jika hasilnya lebih kecil dari $\alpha$ maka variabel bebas (independen) yang dimasukkan dalam model mempunyai pengaruh secara bersamaan terhadap variabel terikat atau dependen. Hasil dari Uji f dapat dilihat pada tabel 6 dan 7 sebagai berikut :

\section{Tabel 6 Model Regresi 1}

Effects Specification

\begin{tabular}{lccc}
\hline \hline \multicolumn{4}{c}{ Cross-section fixed (dummy variables) } \\
\hline \hline F-statistic & 70.90115 & Durbin-Watson stat & 1.874957 \\
Prob(F-statistic) & 0.000000 & & \\
\hline \hline
\end{tabular}

Sumber: Data diolah 
Tabel 7

\section{Model Regresi 2}

Effects Specification

\begin{tabular}{lccc}
\hline \hline \multicolumn{4}{c}{ Cross-section fixed (dummy variables) } \\
\hline \hline F-statistic & 99.48633 & Durbin-Watson stat & 2.018808 \\
Prob(F-statistic) & 0.000000 & & \\
\hline \hline
\end{tabular}

Sumber: Data diolah

Pada model regresi pertama, Tabel 6 menunjukkan bahwa Prob (F-statistic) mempunyai nilai 0 lebih kecil dari $\alpha(0,05)$ menunjukkan bahwa variabel Debt to Equity Ratio (DER), Dividend Payout Ratio (DPR), dan Earning Per Share (EPS) secara simultan mempunyai pengaruh terhadap nilai perusahaan.

Pada model regresi kedua Tabel 7 menunjukkan bahwa Prob (F-statistic) mempunyai nilai 0 lebih kecil dari $\alpha(0,05)$ menunjukkan bahwa variabel Debt to Equity Ratio (DER), Dividend Payout Ratio (DPR), Earning Per Share (EPS), dan nilai perusahaan secara simultan mempunyai pengaruh terhadap harga saham.

\section{Uji secara parsial (Uji t)}

Pengujian hipotesis dilakukan dengan cara membandingkan antara probabilitas dengan tingkat kesalahan $(\alpha)=5 \%$ dengan melihat pada data tabel 8 sehingga dapat diinpretasikan hasil sebagai berikut:

\begin{tabular}{crrrr}
\multicolumn{5}{c}{ Tabel 8 } \\
Uji t \\
\hline \hline Variable & Coefficient & Std. Error & t-Statistic & Prob. \\
\hline \hline C & 2.498383 & 0.937441 & 2.665110 & 0.0092 \\
DER & 0.928174 & 0.451562 & 2.055474 & 0.0428 \\
DPR & -0.008091 & 0.009897 & -0.817499 & 0.4159 \\
EPS & 0.001016 & 0.001051 & 0.966501 & 0.3365 \\
\hline C & 2368.475 & 1250.812 & 1.893549 & 0.0616 \\
DER & -534.5804 & 593.2276 & -0.901139 & 0.3700 \\
DPR & -36.95101 & 12.74601 & -2.899025 & 0.0047 \\
EPS & 10.50605 & 1.355559 & 7.750339 & 0.0000 \\
PBV & 925.7478 & 137.5457 & 6.730475 & 0.0000 \\
\hline \hline
\end{tabular}

Sumber: Data diolah

\section{Pengaruh Debt to Equity Ratio terhadap Nilai Perusahaan}

Debt to Equity Ratio (DER) memiliki koefisien regresi positif sebesar 0,928 dengan probabilitas 0,0428 yang lebih kecil dari $\alpha(0,05)$. Berdasarkan hal tersebut dapat disimpulkan bahwa variabel Debt to Equity Ratio berpengaruh positif terhadap Price to Book Value. Hasil penelitian ini sejalan dengan hasil penelitian Marlina (2013) yang menunjukkan bahwa Debt to Equity Ratio berpengaruh positif terhadap nilai perusahaan dan tidak mendukung penelitian Nasehah dan Widyarti (2012) yang 
mengungkapkan bahwa Debt to Equity Ratio berpengaruh negatif terhadap nilai perusahaan.

\section{Pengaruh Dividend Payout Ratio terhadap Nilai Perusahaan}

Dividend Payout Ratio (DPR) memiliki koefisien regresi negatif sebesar 0,008 dengan probabilitas 0,4159 yang lebih besar dari $\alpha(0,05)$. Berdasarkan hal tersebut dapat disimpulkan bahwa variabel Dividend Payout Ratio tidak berpengaruh terhadap nilai perusahaan. Hasil penelitian ini sejalan dengan hasil penelitian Hidayati (2010) dan Wardjono (2010) yang menunjukkan bahwa Dividend Payout Ratio tidak berpengaruh terhadap nilai perusahaan dan tidak mendukung penelitian Nasehah dan Widyarti (2012) yang mengungkapkan bahwa Dividend Payout Ratio berpengaruh positif terhadap nilai perusahaan.

\section{Pengaruh Earning Per Share terhadap Nilai Perusahaan}

Earning Per Share (EPS) memiliki koefisien regresi positif sebesar 0,001 dengan probabilitas 0,3365 yang lebih besar dari $\alpha(0,05)$. Berdasarkan hal tersebut dapat disimpulkan bahwa variabel Earning Per Share tidak berpengaruh terhadap nilai perusahaan. Hasil penelitian ini sejalan dengan hasil penelitian Mindra dan Erawati (2014),dan Christiana dan Putri (2017) yang menunjukkan bahwa Earning Per Share tidak berpengaruh terhadap nilai perusahaan dan tidak mendukung penelitian Chaidir (2015) yang mengungkapkan bahwa Earning Per Share berpengaruh positif terhadap nilai perusahaan.

\section{Pengaruh Debt to Equity Ratio terhadap Harga Saham}

Debt to Equity Ratio (DER) memiliki koefisien regresi negatif sebesar 534,58 dengan probabilitas 0,37 yang lebih besar dari $\alpha(0,05)$. Berdasarkan hal tersebut dapat disimpulkan bahwa variabel Debt to Equity Ratio tidak berpengaruh terhadap harga saham. Hasil penelitian ini sejalan dengan hasil penelitian Raharjo dan Muid (2013) yang menunjukkan bahwa Debt to Equity Ratio tidak berpengaruh terhadap harga saham dan tidak mendukung penelitian Dewi dan Suaryana (2013) yang mengungkapkan bahwa Debt to Equity Ratio berpengaruh negatif terhadap harga saham.

\section{Pengaruh Dividend Payout Ratio terhadap Harga Saham}

Dividend Payout Ratio (DPR) memiliki koefisien regresi negatif sebesar 36,951 dengan probabilitas 0,0047 yang lebih kecil dari $\alpha(0,05)$. Berdasarkan hal tersebut dapat disimpulkan bahwa variabel Dividend Payout Ratio berpengaruh negatif terhadap harga saham. Hasil penelitian ini sejalan dengan hasil penelitian Dewi dan Sudiartha (2014) yang menunjukkan bahwa Dividend Payout Ratio berpengaruh negatif terhadap harga saham dan tidak mendukung penelitian Rahmawati dan Suryono (2017) yang mengungkapkan bahwa Dividend Payout Ratio berpengaruh positif terhadap harga saham.

\section{Pengaruh Earning Per Share terhadap Harga Saham}

Earning Per Share (EPS) memiliki koefisien regresi positif sebesar 10,506 dengan probabilitas 0 yang lebih kecil dari $\alpha(0,05)$. Berdasarkan hal tersebut dapat disimpulkan bahwa variabel Earning Per Share berpengaruh positif terhadap harga saham. Hasil penelitian ini sejalan dengan hasil penelitian Dewi dan Suaryana (2013), Rahmawati dan Suryono (2017), dan Sari dan Santoso (2017) yang menunjukkan bahwa Earning Per Share berpengaruh positif terhadap harga saham.

\section{Pengaruh Nilai Perusahaan terhadap Harga Saham}

PBV memiliki koefisien regresi positif sebesar 925,748 dengan probabilitas 0 yang lebih kecil dari $\alpha(0,05)$. Berdasarkan hal tersebut dapat disimpulkan bahwa 
variabel nilai perusahaan berpengaruh positif terhadap harga saham. Hasil penelitian ini sejalan dengan hasil penelitian Dewi dan Suaryana (2013) yang menunjukkan bahwa nilai perusahaan berpengaruh positif terhadap harga saham.

\section{Koefisien Determinasi}

Uji koefisien determinasi bertujuan untuk mengukur seberapa jauh kemampuan model dalam menerangkan variasi variabel terikat. Nilai Koefisien determinasi adalah antara 0 dan 1. Nilai $R$-squared yang kecil berarti kemampuan variabel-variabel independen dalam menjelaskan variasi variabel dependen terbatas (Ghozali, 2007). Nilai yang mendekati 1 berarti variasi variabel independen memberikan hampir semua informasi yang dibutuhkan untuk memprediksi variasi variabel dependen. Hasil dari uji koefisien determinasi dapat dilihat pada Tabel 9 sebagai berikut :

\section{Tabel 9 \\ Koefisien Determinasi}

\begin{tabular}{cccc}
\multicolumn{5}{c}{ Effects Specification } \\
\hline \hline \multicolumn{4}{c}{ Cross-section fixed (dummy variables) } \\
\hline \hline R-squared & 0.963070 & Mean dependent var & 4.452750 \\
Adjusted R-squared & 0.949487 & S.D. dependent var & 9.093147 \\
\hline \hline R-squared & 0.974474 & Mean dependent var & 9839.158 \\
Adjusted R-squared & 0.964678 & S.D. dependent var & 13950.89 \\
\hline \hline Sumber: Data diolah & & &
\end{tabular}

Besarnya nilai koefisien determinasi model regresi pertama ditunjukkan dengan data $R$-squared pada Tabel 9 bagian atas. Nilai $R$-squared sebesar 0,963070 menunjukkan bahwa secara bersama-sama variabel Debt to Equity Ratio (DER), Dividend Payout Ratio (DPR), dan Earning Per Share (EPS) mempunyai kontribusi menjelaskan Price to Book Value (PBV) sebesar 96,31\%, sedangkan sisanya sebesar $3,69 \%$ (100\% - 96,31\%) dijelaskan oleh variabel lain yang tidak diteliti atau tidak dimasukkan dalam model penelitian.

Besarnya nilai koefisien determinasi model regresi kedua ditunjukkan dengan data $R$-squared pada Tabel 9 bagian bawah. Nilai $R$-squared sebesar 0,963070 menunjukkan bahwa secara bersama-sama variabel Debt to Equity Ratio (DER), Dividend Payout Ratio (DPR), dan Earning Per Share (EPS) mempunyai kontribusi menjelaskan Price to Book Value (PBV) sebesar 96,31\%, sedangkan sisanya sebesar $3,69 \%(100 \%$ - 96,31\%) dijelaskan oleh variabel lain yang tidak diteliti atau tidak dimasukkan dalam model penelitian.

\section{PENUTUP}

Berdasarkan dari hasil penelitian, dapat disimpulkan bahwa Debt to Equity Ratio berpengaruh positif terhadap nilai perusahaan, Dividend Payout Ratio dan Earning Per Share tidak berpengaruh terhadap nilai perusahaan, Debt to Equity Ratio tidak berpengaruh terhadap harga saham, Dividend Payout Ratio berpengaruh negatif terhadap harga saham, Earning Per Share dan nilai perusahaan berpengaruh positif terhadap harga saham.

Berdasarkan hasil penelitian diatas, maka sangat penting bagi investor untuk memperhatikan profitabilitas perusahaan yang ditunjukkan dengan Earning Per Share 
dan nilai perusahaan yang ditunjukkan dengan Price to Book Value sebelum memutuskan untuk berinvestasi saham. Profitabilitas dan nilai perusahaan yang baik diharapkan dapat dijadikan acuan bagi investor untuk membeli saham perusahaan sehingga semakin banyak pembelian saham perusahaan akan mengakibatkan harga saham perusahaan naik. Bagi perusahaan penerbit saham hendaknya dapat meningkatkan nilai perusahaan dengan cara menambah modal perusahaan melalui hutang yang digunakan untuk meningkatkan kinerja perusahaan sehingga investor tertarik untuk membeli saham perusahaan yang mengakibatkan harga saham perusahaan naik.

\section{DAFTAR PUSTAKA}

Arfan, I. 2008. Akuntansi Lingkungan dan Pengungkapannya. Yogyakarta: Graha Ilmu.

Arikunto, S. 2010. Prosedur Penelitian Suatu pendekatan praktik. Jakarta: PT. Rineka Cipta.

Athanasius, T. 2012. Berinvestasi Saham. Jakarta: PT. Elex Media Komputindo.

Atmaja, L.S \& Thomdean. 2011. Who Wants to be A Smiling Investor. Jakarta: Kepustakaan Populer Gramedia (KPG).

Atmaja, L.S. 2008. Teori dan Praktek Manajemen Keuangan. Yogyakarta: Penerbit ANDI.

Chaidir. 2015. Pengaruh Struktur Modal, Profitabilitas, dan Pertumbuhan Perusahaan terhadap Nilai Perusahaan pada Perusahaan Sub Sektor Transportasi yang Tercacat di Bursa Efek Indonesia Periode 2012-2014. Jurnal Ilmiah Manajemen Fakultas Ekonomi. vol. 1. no. 2: hal. 1-21.

Darmadji, T \& H. Fakhruddin. 2006. Pasar Modal di Indonesia. Jakarta: Salemba Empat.

Dewi, P.D.A \& I.G.N.A Suaryana. 2013. Pengaruh EPS, DER, dan PBV terhadap Harga Saham. E-Jurnal Akuntansi Universitas Udayana. vol. 4. no. 1: hal. 215229.

Frensidy, B. 2017. Angka dan Rasio Penting di Mata Investor. Diunduh di https://kolom.kontan.co.id/news/814/Angka-dan-rasio-penting-di-mata-investor tanggal 20 Agustus 2018.

Gujarati, D.N. 2012. Dasar-dasar Ekonometrika. Buku 2. Edisi 5. Terjemahan oleh R.C. Mangunsong. Jakarta: Salemba Empat.

Hanafi. 2004. Manajemen Keuangan. Yogyakarta: BPFE.

Hartono, J. 2008. Teori Portofolio Dan Analisis Investasi. Yogyakarta: BPFE.

Hidayati, E.E. 2010. Analisis Pengaruh DER, DPR, ROE, dan Size terhadap PBV Perusahaan Manufaktur yang Listing di BEI Periode 2005-2007. Tesis. Semarang: Universitas Diponegoro.

Husnan, S. 2003. Dasar-Dasar Teori Portofolio dan Analisis Sekuritas. Edisi Ketiga. Yogyakarta: UPP AMP YKPN.

Kasmir. 2012. Analisis Laporan Keuangan. Jakarta: PT. Raja Grafindo Persada.

Kuncoro, M. 2013. Metode Riset Untuk Bisnis \& Ekonomi. Edisi Keempat. Jakarta: Erlangga.

Laopodis, N.K. 2013. Understanding Investments: Theories and Strategies. New York: Routledge.

Lynch, P. 2016. Strategi Pemilihan Saham Peter Lynch. Diunduh di http://www.analisissahamfundamental.com/2016/09/strategi-pemilihan-sahampeter-lynch.html tanggal 20 Agustus 2018. 
Marlina, T. 2013. Pengaruh Earning Per Share, Return On Equity, Debt To Equity Ratio dan Size terhadap Price To Book Value. Jurnal Ilmiah Akuntansi Kesatuan. vol. 1. no.1: hal. 65-76.

Mayangsari, A. 2015. Analisis Pengaruh Current Ratio, Debt to Equity Ratio, dan Return On Assets terhadap Dividend Payout Ratio (Pada Perusahaan Barang Konsumsi yang Terdaftar di Bursa Efek Indonesia Periode 2010-2013). Tesis. Surabaya: Politeknik Negeri Surabaya.

Mindra, S \& T. Erawati. 2014. Pengaruh Earning Per Share (EPS), Ukuran Perusahaan, Profitabilitas, dan Leverage terhadap Nilai Perusahaan (Studi Kasus pada Perusahaan Manufaktur yang Terdaftar di Bursa Efek Indonesia pada Tahun 2009-2011. Jurnal Akuntansi. vol. 2. no. 2. Yogyakarta: Universitas Sarjanawiyata Tamansiswa.

Murhadi, W.R. 2013. Analisis Laporan Keuangan, Proyeksi dan Valuasi Saham. Jakarta: Salemba Empat.

Nachrowi, N. D \& H. Usman. 2006. Pendekatan Populer dan Praktis Ekonometrika untuk Analisis Ekonomi dan Keuangan. Jakarta: LPFE.

Nasehah, D \& E.T. Widyarti. 2012. Analisis Pengaruh ROE, DER, DPR, Growth dan Firm Size terhadap Price to Book Value (PBV) (Studi Kasus pada Perusahaan Manufaktur yang Listed di BEI Periode Tahun 2007-2010). Diponegoro Journal of Management. vol. 1. no. 1: hal. 1-9.

Raharjo, D \& D. Muid. 2013. Analisis Pengaruh Faktor-faktor Fundamental Rasio Keuangan terhadap Perubahan Harga Saham. Diponegoro Journal of Accounting. vol. 2. no. 2: hal. 1-11.

Rahmawati, D \& B. Suryono. 2017. Pengaruh DPR, EPS, dan DER terhadap Harga Saham. Jurnal Ilmu dan Riset Akuntansi. vol. 6. no. 6. Surabaya: Sekolah Tinggi Ilmu Ekonomi Indonesia.

Rhamadana, R. B \& Triyonowati. 2016. Analisis Rasio Keuangan untuk Menilai Kinerja Keuangan pada PT. H.M SAMPOERNA Tbk. Jurnal Ilmu dan Riset Manajemen. vol. 5. no. 7.

Salim H.S \& B. Sutrisno. 2008. Hukum Investasi di Indonesia. Jakarta: PT. Raja Grafinfo Persada.

Sari, L.A \& B.H. Santoso. 2017. Pengaruh EPS, DER, PBV dan NPM terhadap Harga Saham Perusahaan Properti. Jurnal Ilmu dan Riset Akuntansi. vol. 6. no. 8. Surabaya: Sekolah Tinggi Ilmu Ekonomi Indonesia.

Septiani, N.N.D \& N.L. Supadmi. 2014. Analisis Pengaruh Beta terhadap Return Saham Periode Sebelum dan Saat Krisis Global (Studi pada Perusahaan Perbankan di BEI). E-Jurnal Akuntansi Universitas Udayana. vol. 7. no. 1: hal. 19-32.

Sitompul, K. 2011. Analisis Pengaruh Faktor-faktor Fundamental terhadap Harga Saham Perusahaan Real Estate dan Property yang Terdaftar di Bursa Efek Indonesia. Tesis. Medan: Universitas Sumatera Utara.

Sugiyono. 2010. Metode Penelitian Kuantitatif Kualitatif \& RND. Bandung: Alfabeta.

Tandelilin, E. 2010. Portofolio dan Investasi: Teori dan Aplikasi. Edisi 1. Yogyakarta: Kanisius.

Triani, I. 2013. Pengaruh Four Factor Model Carhart terhadap Return pada Reksa Dana Top Five Star dan Top Four Star Periode 2008-2012. Tesis. Yogyakarta: Universitas Atma Jaya.

Wardjono. 2010. Analisis Faktor-faktor yang Mempengaruhi Price to Book Value dan Implikasinya pada Return Saham (Studi Kasus pada Perusahaan Manufaktur 
yang Terdaftar di BEI). Dinamika Keuangan dan Perbankan. hal. 83-96. Semarang: Universitas Stikubank.

Widarjono, A. 2007. Ekonometrika: Teori dan Aplikasi Untuk Ekonomi dan Bisnis. Edisi 2. Yogyakarta: Ekonisia FE.

Widyantari, A.A.A.P. 2011. Opini Going Concern dan Faktor-faktor yang memengaruhinya: Studi pada Perusahaan Manufaktur di Bursa Efek Indonesia. Tesis. Denpasar: Universitas Udayana. 